\title{
Pensononowoor
}

2015, vol. 74, 59-67

http://dx.doi.org/10.12657/denbio.074.006

\author{
Mustafa Yilmaz, Tolga Ok
}

\section{Seed characteristics of Flueggea anatolica, an endangered forest shrub species}

\author{
Received: 16 July 2014; Accepted: 13 January 2015
}

\begin{abstract}
The Kadincik shrub (Flueggea anatolica) is one of the endemic forest shrub species in Turkey. In this study, the morphological and physiological characteristics of $F$. anatolica seeds from three provenances (Tarsus, Kozan, Andırın) were investigated. The average 1000-seed weight was $4.9 \mathrm{~g}$. There were significant differences between seeds from the different provenances in terms of their morphological characteristics, with the seeds from the Kozan provenance having the smallest seeds in terms of weight, thickness, and width. The seeds germinated at similarly high rates $(90 \pm 2 \%)$ at $16^{\circ} \mathrm{C}, 20^{\circ} \mathrm{C}, 24^{\circ} \mathrm{C}$, and $28^{\circ} \mathrm{C}$. However, the germinations occurred earlier at $24^{\circ} \mathrm{C}$ and $28^{\circ} \mathrm{C}$, with $24^{\circ} \mathrm{C}$ appearing to be the most appropriate germination temperature. The results indicated that $\mathrm{F}$. anatolica seeds have physiological dormancy, requiring approximately 10 weeks of prechilling for dormancy removal and germination. A 4-week warm-incubation period at $24^{\circ} \mathrm{C}$ prior to the prechilling treatment had only a slight effect on the prechilling duration time required to remove dormancy. Seeds stored in the refrigerator $\left(+4^{\circ} \mathrm{C}\right)$ with a $2.7 \%$ or $4.0 \%$ moisture content conserved their high initial germination rates after one year of storage. The average germination rate of the prechilled seeds redried to an $8 \%$ moisture content and stored for one year at $4^{\circ} \mathrm{C}$ dropped from $92.7 \%$ to $63.6 \%$. Basing on the results of this study, the suggested moisture content and storage temperature for storing F. anatolica seeds are $3-8 \%$ and $4^{\circ} \mathrm{C}$ or less, respectively.
\end{abstract}

Additional key words: Flueggea anatolica, seed, dormancy, prechilling

Address: M. Yilmaz, BTU Faculty of Forestry, Department of Forest Engineering 16330 Yıldırım, Bursa, Turkey, email: mustafa.yilmaz@btu.edu.tr

T. Ok, KSU Faculty of Forestry, Kakramanmara, Turkey, tolgaok@ksu.edu.tr

\section{Introduction}

The Kadıncık shrub (Flueggea anatolica Gemici), a member of the Phyllanthaceae family sensu stricto or Euphorbiaceae family senso lato (Barker and Van Welzen 2010; Govaerts et al. 2000; Hoffman et al. 2006; Hoffman 2007), is a critically endangered forest species in Turkey (Ekim et al. 2000; Özhatay et al. 2003; Serdar 2008). The species was discovered in recent decades (Gemici 1992; Gemici et al. 1996) and is one of the woody plants endemic to Turkey. Flueggea species are mostly found in relict populations (Webster 1984), and F. anatolica is described as a Tertiary relict plant (Gemici and Leblebici 1995).

There exist currently only three small distributions of the species (Ok 2006; Ok and Avşar 2007) with provenances in Tarsus, Kozan, and Andırın. In very limited areas, $F$. anatolica individuals arise primarily from sprouts, regeneration from seeds being rare. The seed of a plant is a symbol of its sustaina- 
bility and diversity (Bradford and Cohn 1998), and for both in situ and ex situ conservation, an exploration of the seed characteristics of the species is needed.

Temperature is one of the most influential factors affecting the germination behavior of seeds (Bewley et al. 2013; Schmidt 2000). The temperature requirements of seeds for germination vary according to species, variety, and occasionally, provenance. The optimum germination temperature is also related to the ecology of the species location (Fenner and Thompson 2005). The favorable temperature for seeds is the temperature that provides the highest percentage of germination within the shortest period (Copeland and McDonald 2001).

Seed dormancy is extremely prevalent in temperate regions of the world (Suszka et al. 1996), with the depth of dormancy varying greatly and dependent on the species, provenance location, and individuals within the provenance (Smith et al. 2002; Desai 2004). The dormancy phenomenon of Flueggea species was unknown. Studies of seed storage, which is particularly important for endemic plant species such as $F$. anatolica, have also been increasing in recent decades. Before storing seeds, the storage characteristics of the species should be investigated.

The main objectives of this first detailed study on F. anatolica seeds were (1) to find out the morphological traits of the seeds; and (2) to explore the dormancy phenomenon, the pretreatment requirements, the effect of temperature on germination, and the storage characteristics of seeds. The interpopulation variation of seeds was also explored.

\section{Materials and Methods}

Seeds were collected from trees from three small disjunct populations in southern Turkey with provenances in Tarsus, Kozan (September 22, 2009), and Andirın (October 6, 2009) (Table 1). F. anatolica fruits have an active ballistic dispersal mechanism, and the seeds are scattered during the fruit drying phase (Fig. 1). The seeds were therefore air-dried in the laboratory in perforated bags to an moisture content (MC) of approximately $8 \%$. The MC of the seeds was determined by the low-temperature oven method for 17 hours at $104 \pm 1{ }^{\circ} \mathrm{C}$ (International Seed Testing Association 1996) and was expressed as the percentage of the fresh weight of the seed. Fresh seeds were also collected from Tarsus (August 1, 2009) and Andirın (September 3, 2009) to determine the maturation of early-collected seeds.

\section{Morphological characteristics of $F$. anatolica seeds}

One hundred seeds from each provenance were randomly selected, and for each seed, three traits (length, width, and thickness) were measured with a sensitivity of $0.01 \mathrm{~mm}$.

\section{Dormancy level and pretreatment requirements}

The preliminary germination tests demonstrated that $F$. anatolica seeds are characterized by physiological dormancy. Therefore, to determine the presence

Table 1. Seed material used in the study

\begin{tabular}{lcccccc}
\hline $\begin{array}{l}\text { Provenances } \\
\text { (Populations) }\end{array}$ & Seed collection & Latitude & Longitude & Altitude $[\mathrm{m}]$ & $\begin{array}{c}\text { Annual rainfall } \\
{[\mathrm{mm}]}\end{array}$ & $\begin{array}{c}\text { Mean temperature } \\
{\left[{ }^{\circ} \mathrm{C}\right]}\end{array}$ \\
\hline Tarsus & September 22, 2009 & $37^{\circ} 05^{\prime}$ & $34^{\circ} 47^{\prime}$ & 300 & 787.8 & 16.3 \\
Kozan & September 22, 2009 & $37^{\circ} 31^{\prime}$ & $35^{\circ} 52^{\prime}$ & 380 & 941.7 & $18.93^{*}$ \\
Andirın & October 6, 2009 & $37^{\circ} 32^{\prime}$ & $36^{\circ} 18^{\prime}$ & 970 & 1477.2 & 3.75 \\
\hline
\end{tabular}

* Air dry weight, about $8 \%$ moisture content.
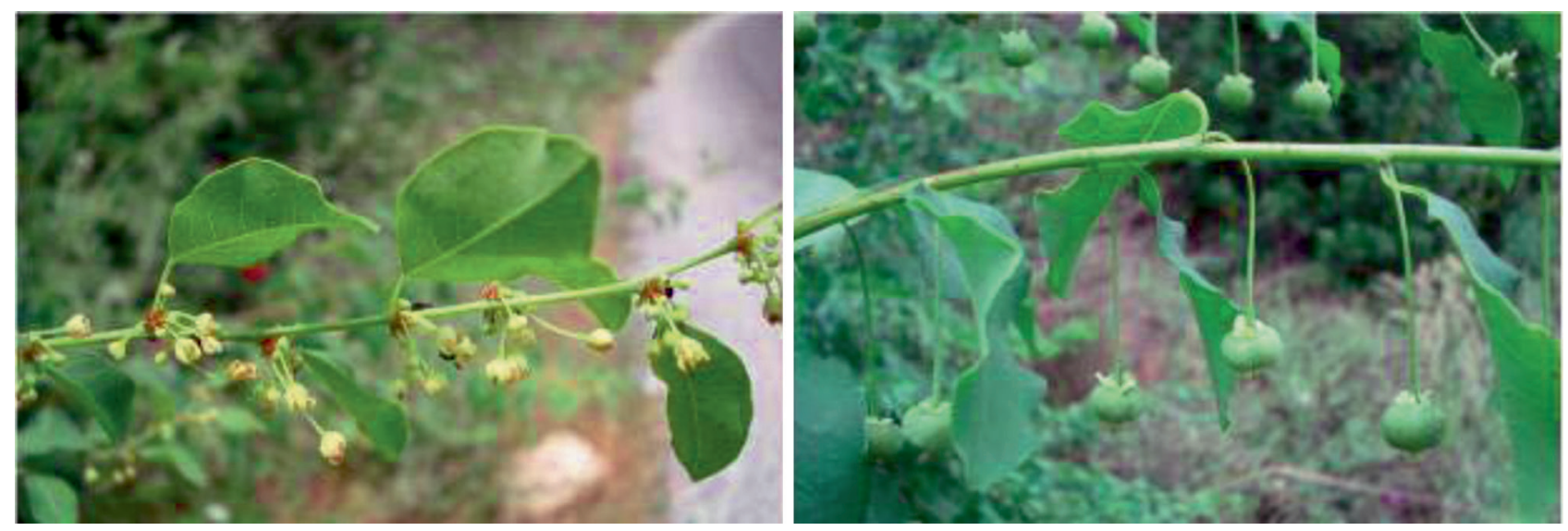

Fig. 1. The development of F. anatolica fruits (Ok 2006) 
Table 2. Pretreatments of the F. anatolica seeds before the germination tests

\begin{tabular}{ll}
\hline 1 & 8 -week prechilling at $4^{\circ} \mathrm{C}$ \\
2 & 10 -week prechilling at $4^{\circ} \mathrm{C}$ \\
3 & 12 -week prechilling at $4^{\circ} \mathrm{C}$ \\
4 & 4 -week warm incubation at $24^{\circ} \mathrm{C}+5$-week prechilling at $4^{\circ} \mathrm{C}$ \\
5 & 4 -week warm incubation at $24^{\circ} \mathrm{C}+7$-week prechilling at $4^{\circ} \mathrm{C}$ \\
6 & 4 -week warm incubation at $24^{\circ} \mathrm{C}+9$-week prechilling at $4^{\circ} \mathrm{C}$ \\
\hline
\end{tabular}

of dormancy, dormancy depth, and pretreatment requirements for germination, the seeds from each of the three provenances (Tarsus, Kozan, and Andirın) were pretreated with six different pretreatment regimes (Table 2). In the last three pretreatments, the seeds were incubated at $24^{\circ} \mathrm{C}$ for 4 weeks before subjecting them to the prechilling treatments $\left(4^{\circ} \mathrm{C}\right)$. During both incubations $\left(24^{\circ} \mathrm{C}\right.$ and $\left.4^{\circ} \mathrm{C}\right)$, the seeds were placed on moist double-layered filter paper in Petri dishes (maximum MC of $F$. anatolica is about $27 \%$ ). To retain the moisture during the pretreatments, distilled water was added by spraying when necessary.

\section{Seed storage}

Seeds of three provenances (Table 1) were stored under three conditions: (1) dormant seeds with a $4.0 \% \mathrm{MC}$, (2) dormant seeds with a $2.7 \% \mathrm{MC}$, and (3) nondormant seeds with an $8.0 \% \mathrm{MC}$, with the storage in sealed containers at $4^{\circ} \mathrm{C}$ in the dark for one year. A desiccator was used to reduce the $\mathrm{MC}$ of the seeds to $2.7 \%$ and $4.0 \%$. To obtain the nondormant seeds, the seeds were prechilled for 10 weeks and then dried again to return them to an $8.0 \% \mathrm{MC}$. The germination tests were conducted before and after storage at $24^{\circ} \mathrm{C}$.

\section{Maturation of seeds}

The early-collected seeds harvested from Tarsus (August 1, 2009) and Andirın (September 3, 2009) were used in germination tests at $24^{\circ} \mathrm{C}$ after 10 weeks of prechilling.

\section{Germination temperature}

To determine the effect of temperature on the germination behavior, seeds from the three provenances were prechilled in Petri dishes on moist double-layered filter paper for 10 weeks in the refrigerator $\left(4^{\circ} \mathrm{C}\right)$ with the MC of the seeds maintained at the maximum level (27\%). To maintain the seed MC at 25-27\% MC, distilled water was sprayed on the seeds once every two weeks. After the prechilling treatments, the seeds were removed for germination testing under four different temperature regimes with constant temperatures of $16^{\circ} \mathrm{C}, 20^{\circ} \mathrm{C}, 24^{\circ} \mathrm{C}$, and $28^{\circ} \mathrm{C}$.

\section{Germination tests}

The germination tests were performed on double-layered filter paper in 12-cm diameter Petri dishes with 150 ( 3 dishes $\times 50$ seeds) seeds at the four temperatures $\left(16^{\circ} \mathrm{C}, 20^{\circ} \mathrm{C}, 24^{\circ} \mathrm{C}\right.$, and $\left.28^{\circ} \mathrm{C}\right)$. When were observed fungal infections, the filter papers were replaced. The seeds were considered germinated when their radicles protruded approximately 3 $\mathrm{mm}$ and displayed geotropism. The Petri dishes were examined every two days, and the germinated seeds were counted and removed. The germination tests were terminated after 28 days.

\section{Germination parameters}

During the germination tests, the percentage of seeds that germinated (GP) and the mean germination time (MGT) were calculated with the following formulas:

1 . Where $G P(\%)$ is the percentage of seeds that germinated, $n_{i}$ is the number of germinated seeds at week $i$, and $N$ is the total number of incubated seeds per test; and

2. Where MGT is the mean germination time, $t_{i}$ is the number of weeks since the beginning of the test, and $n_{i}$ is the number of germinated seeds recorded for week $t_{i}$.

\section{Statistical analyses}

The data for the 1000-seed weight, seed length, thickness, and width, GP, and MGT were evaluated by analyses of variance. The treatment means were tested with Duncan multiple-range tests. Arcsine square root $(\sqrt{ } P)$ transformations were applied to the GP values to normalize the error distributions prior to the variance analyses.

\section{Results}

\section{Morphological characteristics of $F$. anatolica seeds}

F. anatolica seeds demonstrated significant variation in terms of their morphological traits (Table 3, Fig. 2). The average 1000-seed weight was $4.90 \mathrm{~g}$, with the heaviest seeds found in the Tarsus provenance $(5.93 \mathrm{~g})$ and the lightest in the Kozan provenance $(3.75 \mathrm{~g})$. The average length, width, and thickness of the seeds were $2.57 \mathrm{~mm}, 1.93 \mathrm{~mm}$, and $1.71 \mathrm{~mm}$, respectively. In general, the seeds from the provenances were largest in Tarsus and smallest in Kozan, with those from Andırın falling intermediate between them. 
Table 3. 1000-seed weight and dimensions of F. anatolica seeds

\begin{tabular}{lccccc}
\hline & 1000-seed weight [g] & Length [mm] & Width [mm] & Thickness [mm] & 1000-seed weight of early-collected seeds [g] \\
\hline Tarsus & $5.93 \mathrm{a}^{1}$ & $2.69 \mathrm{a}$ & $2.07 \mathrm{a}$ & $1.88 \mathrm{a}$ & 5.87 \\
Kozan & $3.75 \mathrm{c}$ & $2.35 \mathrm{~b}$ & $1.80 \mathrm{c}$ & $1.60 \mathrm{~b}$ & - \\
Andırın & $4.83 \mathrm{~b}$ & $2.67 \mathrm{a}$ & $1.92 \mathrm{~b}$ & $1.65 \mathrm{~b}$ & 4.52 \\
Average & 4.90 & 2.57 & 1.93 & 1.71 & \\
\hline
\end{tabular}

${ }^{1}$ The values on the same column followed by the same small letters are not significantly different at $\mathrm{P}<0.01$.

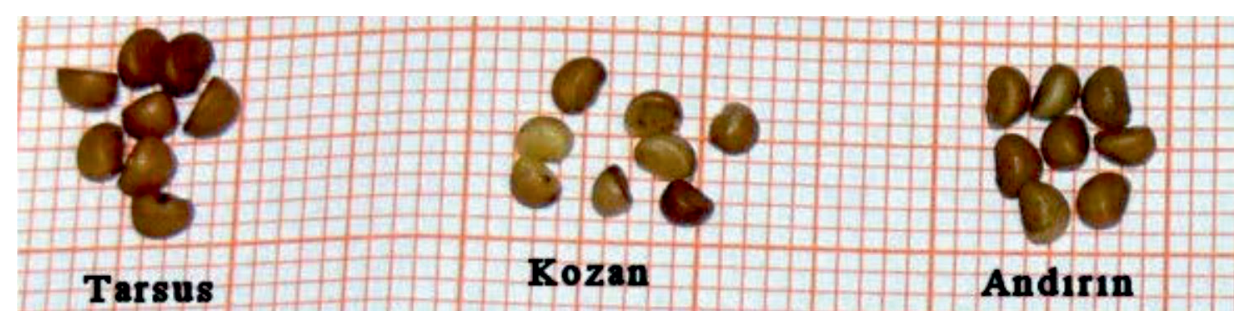

Fig. 2. F. anatolica seeds from the three different provenances

\section{Dormancy depth and prechilling requirements}

Seeds in the control treatment (without any pretreatment) did not germinate. The average germination rates after 8,10 , and 12 weeks of prechilling were $67.6 \%, 92.7 \%$, and $92.2 \%$, respectively (Table 4 ). Prechilling the seeds for 10 or 12 weeks eliminated dormancy completely in seeds of all three provenanc- es, and the seeds reached the highest germination rates under these conditions. A 4-week warm-incubation period prior to the prechilling treatments was partially effective at removing the F. anatolica seed dormancy. Treating seeds with a 4-week warm-incubation period followed by only 5 weeks of prechilling resulted in a higher germination rate than that of seeds only prechilled for 8 weeks (Fig. 3).

Table 4. Germination rates for F. anatolica seeds at $24^{\circ} \mathrm{C}$ after 6 pretreatment regimes.

\begin{tabular}{|c|c|c|c|c|c|c|}
\hline \multirow{2}{*}{ Provenance } & \multicolumn{6}{|c|}{ Germination rate $(\%)$} \\
\hline & 8-w pc & 10-w pc & $12-\mathrm{w} p c$ & 4-w wi $+5 w p c$ & 4-w wi $+7 w p c$ & 4-w wi $+9-w p c$ \\
\hline Tarsus & $48.0 c^{1}$ & $95.3 a$ & $94.0 \mathrm{a}$ & $70.0 \mathrm{~b}$ & $89.3 a$ & $91.3 \mathrm{a}$ \\
\hline Kozan & $75.3 b$ & $90.7 \mathrm{a}$ & $89.3 a$ & $66.0 c$ & $78.7 \mathrm{~b}$ & $92.0 \mathrm{a}$ \\
\hline Andirın & $79.3 c$ & $92.0 \mathrm{a}$ & $93.3 \mathrm{a}$ & $60.7 d$ & $82.0 \mathrm{~b}$ & $84.0 \mathrm{~b}$ \\
\hline Average & $67.6 \mathrm{c}$ & $92.7 \mathrm{a}$ & $92.2 \mathrm{a}$ & $65.6 c$ & $83.3 \mathrm{~b}$ & $89.1 \mathrm{a}$ \\
\hline
\end{tabular}

${ }^{1}$ The values on the same line followed by the same small letters are not significantly different at $\mathrm{P}<0.05$.

Abbreviations: $\mathrm{w}$ - weeks; pc - prechilled $\left(4^{\circ} \mathrm{C}\right)$; wi - warm incubation $\left(24^{\circ} \mathrm{C}\right)$.

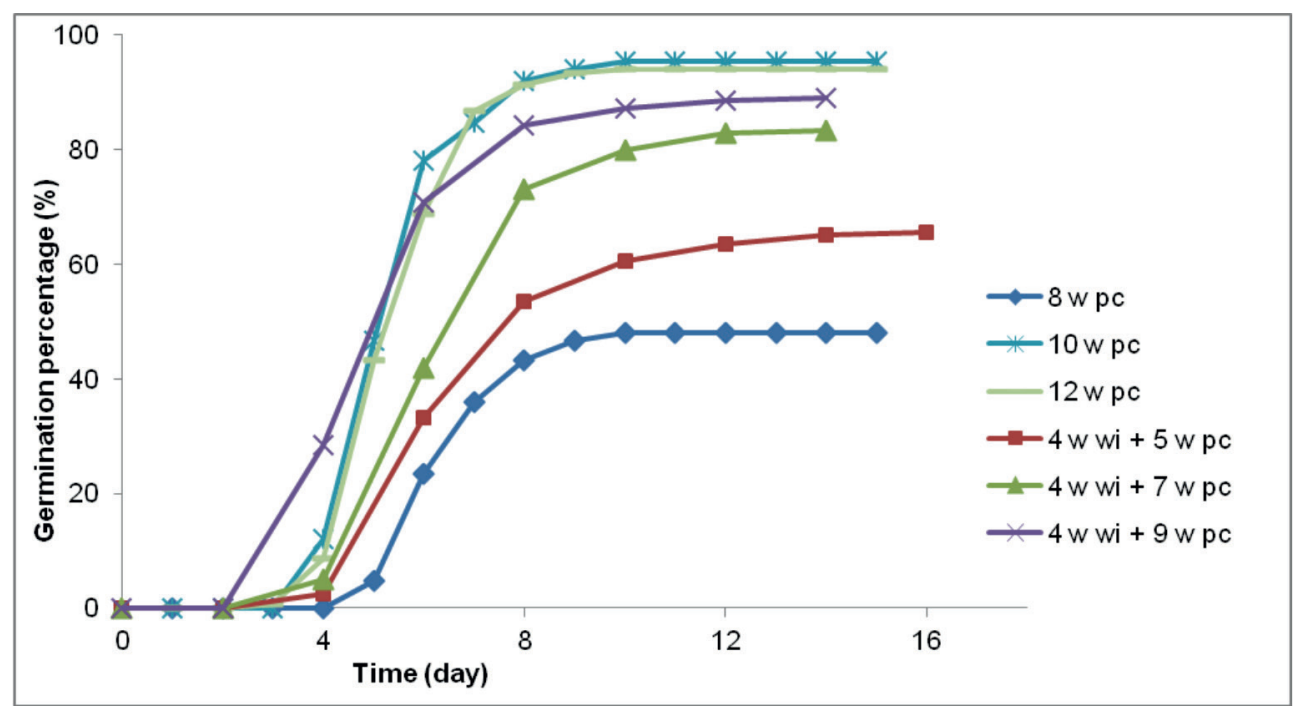

Fig. 3. Average germination rates for $F$. anatolica seeds after different pretreatments Abbreviations: w, weeks; pc, prechilled at $4^{\circ} \mathrm{C}$; wi, warm incubation at $24^{\circ} \mathrm{C}$ 
Table 5. Mean germination times of $F$. anatolica seeds after 6 pretreatment regimes

\begin{tabular}{lccccccc}
\hline \multirow{2}{*}{ Provenance } & \multicolumn{7}{c}{ Mean germination time (days) } \\
\cline { 2 - 8 } & $8-\mathrm{w} \mathrm{pc}$ & $10-\mathrm{w} \mathrm{pc}$ & $12-\mathrm{w} \mathrm{pc}$ & $4 \mathrm{w} w \mathrm{wi}+5-\mathrm{w} \mathrm{pc}$ & $4-\mathrm{w}$ wi $+7-\mathrm{w} \mathrm{pc}$ & $4-\mathrm{w}$ wi +9 -w pc & Average \\
\hline Tarsus & $9.6 \mathrm{~d}^{1}$ & $7.5 \mathrm{~b}$ & $7.6 \mathrm{~b}$ & $8.5 \mathrm{c}$ & $7.7 \mathrm{~b}$ & $6.8 \mathrm{a}$ & $8.0 \mathrm{C}^{2}$ \\
Kozan & $8.1 \mathrm{c}$ & $6.1 \mathrm{a}$ & $6.3 \mathrm{a}$ & $7.1 \mathrm{~b}$ & $7.7 \mathrm{~b}$ & $6.0 \mathrm{a}$ & $6.9 \mathrm{~B}$ \\
Andırın & $7.0 \mathrm{~b}$ & $4.9 \mathrm{a}$ & $4.8 \mathrm{a}$ & $6.9 \mathrm{~b}$ & $6.2 \mathrm{~b}$ & $5.0 \mathrm{a}$ & $5.8 \mathrm{~A}$ \\
Average & $8.2 \mathrm{c}$ & $6.1 \mathrm{a}$ & $6.3 \mathrm{a}$ & $7.5 \mathrm{bc}$ & $7.2 \mathrm{~b}$ & $5.9 \mathrm{a}$ & \\
\hline
\end{tabular}

${ }^{1}$ The values on the same line followed by the same small letters are not significantly different at $\mathrm{P}<0.01$.

${ }^{2}$ The values on the same column followed by the same capital letters are not significantly different at $\mathrm{P}<0.01$.

Abbreviations: $\mathrm{w}$ - weeks; pc - prechilled $\left(4^{\circ} \mathrm{C}\right)$; wi - warm incubation $\left(24^{\circ} \mathrm{C}\right)$.

Table 6. Germination rates of $F$. anatolica seeds at different temperatures after prechilling $\left(4^{\circ} \mathrm{C}\right)$ the seeds for 10 weeks

\begin{tabular}{|c|c|c|c|c|c|}
\hline \multirow{2}{*}{ Provenance } & \multicolumn{4}{|c|}{ Germination temperatures (\%) } & \multirow{2}{*}{ Average } \\
\hline & $16^{\circ} \mathrm{C}$ & $20^{\circ} \mathrm{C}$ & $24^{\circ} \mathrm{C}$ & $28^{\circ} \mathrm{C}$ & \\
\hline Tarsus & $88.0 \mathrm{a}^{1}$ & $90.0 \mathrm{a}$ & $94.0 \mathrm{a}$ & $92.7 \mathrm{a}$ & $92.2 \mathrm{~A}^{2}$ \\
\hline Kozan & $89.3 a$ & $92.0 \mathrm{a}$ & $90.0 \mathrm{a}$ & $92.7 \mathrm{a}$ & $91.6 \mathrm{~A}$ \\
\hline Andirın & $89.3 \mathrm{a}$ & $91.3 \mathrm{a}$ & $90.7 \mathrm{a}$ & $89.3 \mathrm{a}$ & $90.4 \mathrm{~A}$ \\
\hline Average & $88.9 \mathrm{a}$ & $91.1 \mathrm{a}$ & $91.6 \mathrm{a}$ & $91.6 \mathrm{a}$ & \\
\hline
\end{tabular}

${ }^{1}$ The values on the same line followed by the same small letters are not significantly different at $\mathrm{P}<0.01$.

${ }^{2}$ The values on the same column followed by the same capital letters are not significantly different at $\mathrm{P}<0.01$.

Prechilling duration also affected the time required to germinate. In general, the longer the prechilling period, the earlier the germination occurred. The average MGT was roughly between 6 and 8 days. The population factor also had an effect on the average MGT (Table 5). The average time required for seed germination was least for the seeds from Andirın, most for those from Tarsus, with those from Kozan requiring a time intermediate between the other two provenances.

\section{Effect of temperature on germination}

The GPs were similar at all of the tested temperatures $\left(16^{\circ} \mathrm{C}, 20^{\circ} \mathrm{C}, 24^{\circ} \mathrm{C}\right.$, and $\left.28^{\circ} \mathrm{C}\right)$, with seeds of different provenances demonstrating similar germination rates at the four different temperatures (Table 6). In contrast, the MGT distinctly differed at the various temperatures. The overall mean GPs of the seeds from Tarsus, Kozan, and Andırın were 92.2\%, $91.6 \%$, and $90.4 \%$, respectively. Germination was accelerated by an increase in the germination temperature (Table 7), occurring earliest at $24^{\circ} \mathrm{C}$ and $28^{\circ} \mathrm{C}$. The optimum temperature appeared to be approximately $24^{\circ} \mathrm{C}$, where the GP was high and the MGT was shorter than that of the seeds germinated at $16^{\circ} \mathrm{C}$ or $20^{\circ} \mathrm{C}$. Importantly, F. anatolica seeds did not germinate during the $4^{\circ} \mathrm{C}$ prechilling period.

\section{Maturation of $F$. anatolica seeds}

The early-collected $F$. anatolica seeds, harvested in 2009 on August $1^{\text {st }}$ (Tarsus) and September $3^{\text {rd }}$ (Andırın), generally demonstrated high germination rates after 10 weeks of prechilling. For the seeds from the Tarsus provenance, there were no significant differences in GP between the August $1^{\text {st }}$ and September $22^{\text {nd }}$ collections (Fig. 4). In contrast, the GP for the seeds collected in the Andirın provenance, which represents the seed source at the highest altitude for the species, was significantly higher for fully mature seeds collected on October 6th than for the early-collected seeds on September $1^{\text {st }}$. The MGT was similar between the early-collected and mature seeds.

\section{Storage of F. anatolica seeds}

Seeds from the three provenances stored with a $2.7 \%$ or $4.0 \% \mathrm{MC}$ at $4^{\circ} \mathrm{C}$ retained their initial germination rates after one year of storage. The average

Table 7. Mean time until germination of $F$. anatolica seeds incubated at different temperatures after prechilling $\left(4^{\circ} \mathrm{C}\right)$ the seeds for 10 weeks

\begin{tabular}{lcccc}
\hline \multirow{2}{*}{ Provenances } & \multicolumn{4}{c}{ Mean germination time (days) } \\
\cline { 2 - 4 } & $16^{\circ} \mathrm{C}$ & $20^{\circ} \mathrm{C}$ & $24^{\circ} \mathrm{C}$ & $28^{\circ} \mathrm{C}$ \\
\hline Tarsus & $13.20 \mathrm{c}^{1}$ & $7.99 \mathrm{~b}$ & $5.90 \mathrm{a}$ & $6.24 \mathrm{a}$ \\
Kozan & $12.41 \mathrm{c}$ & $7.69 \mathrm{~b}$ & $5.37 \mathrm{a}$ & $5.25 \mathrm{a}$ \\
Andırın & $11.73 \mathrm{c}$ & $6.95 \mathrm{~b}$ & $4.80 \mathrm{a}$ & $7.68 \mathrm{AB}$ \\
Average & $12.45 \mathrm{c}$ & $7.54 \mathrm{~b}$ & $5.36 \mathrm{a}$ & $7.07 \mathrm{~A}$ \\
\hline
\end{tabular}

${ }^{1}$ The values on the same line followed by the same small letters are not significantly different at $\mathrm{P}<0.01$.

${ }^{2}$ The values on the same column followed by the same capital letters are not significantly different at $\mathrm{P}<0.01$. 


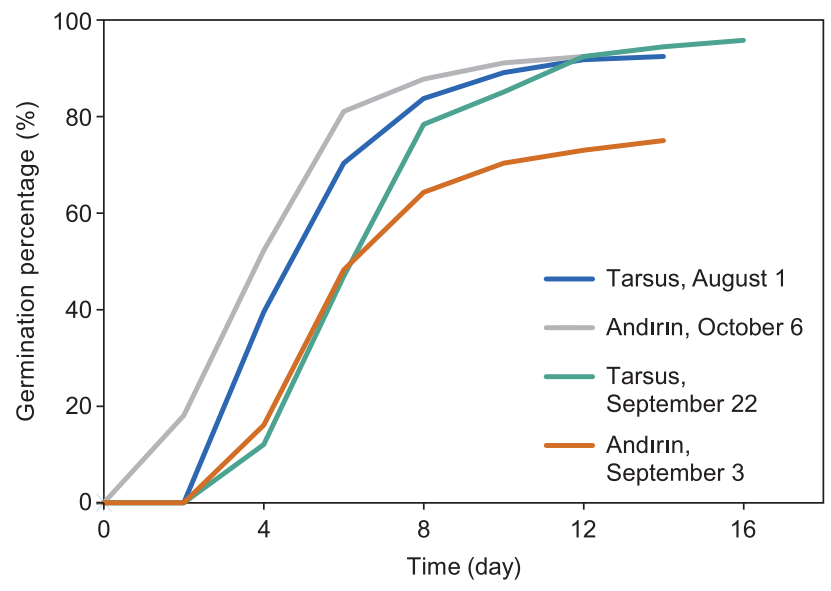

Fig. 4. Germination percentages of Flueggea anatolica Gemici seeds collected on different dates after prechilling $\left(4^{\circ} \mathrm{C}\right)$ for 10 weeks

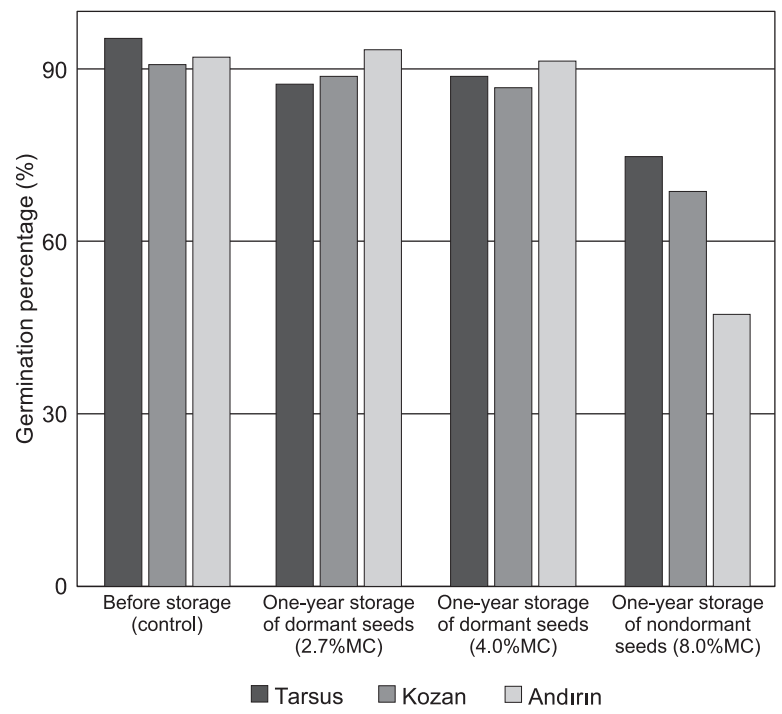

Fig. 5. Germination percentages of dormant and nondormant $F$. anatolica seeds after storage lasting one year at $4^{\circ} \mathrm{C}$

MC: Moisture content

GPs for the seeds prior to storage and after storage for one year with $2.7 \%$ or $4.0 \%$ MC were $92.7 \%$, $89.8 \%$, and $88.9 \%$, respectively (Fig. 5). In contrast, the GP of the nondormant seeds significantly declined after one year of storage in comparison to the initial germination rate, with a decline of $29.1 \%(92.7 \%$ to $63.6 \%)$ in the average germination rate after storage. The loss of viability in the nondormant seeds after storage was relatively higher for seeds from the Andirin provenance than that for seeds from the other two provenances. The mean germination time was similar for the dormant seeds, while the nondormant seeds germinated significantly more slowly.

\section{Discussion}

The Kadıncık shrub ( $F$. anatolica), a recently discovered endemic woody species, is distributed in three small populations in southern Turkey (Ok and Avşar 2009). This first detailed study of seed characteristics of $F$. anatolica revealed the morphological characteristics, the depth of dormancy, the effects of temperature on the germination behavior, and the storage traits. Although the germination tests were terminated after 28 days, the experiments appeared to show that the test period of two weeks was a sufficient germination time for the F. anatolica seeds.

Based on the metric traits of $F$ anatolica seeds, the three provenances differed significantly (Table 3). Both the seed dimensions and seed weights varied, particularly between provenances. This result is consistent with the hypothesis that the habitat variation of a species is one of the factors that shapes seed morphology (Fenner and Thompson 2005).

F. anatolica seeds are generally bigger than those of other Flueggea species (Thomson 2006; Royal Botanic Garden Kew 2014), and the 1000-seed weight of F. anatolica (4.90 g) was heavier than that of F. spirei Beille (2.58 g) and F. virosa (Willd.) Voigt (3.45 g) (Royal Botanic Garden Kew 2014). Seed size plays a vital role in the ecology of a plant species, and genetic traits and environmental factors are the major determinants of seed size and shape (Leishman et al. 2000; Flores 2002). The seed mass is also highly dependent on environmental conditions during seed development (Michaels et al. 1988; Castro et al. 2006). In this study, significant variations were observed within and among the provenances in terms of seed size. Similar variations have been recorded in many other tree species including Fagus sylvatica L. (Thomsen and Kjaer 2002), Pinus sylvestris L. (Boydak 1975), Cedrus libani A.Rich. (Odabaşı 1967), Pinus brutia Ten. (Șefik 1964), F. ornus subsp. cilicica (Lingelsh.) Yalt. (Yilmaz and Tonguç 2009), Fagus orientalis Lipsky (Yilmaz 2005), Sorbus spp. L. (Bednorz et al. 2006), and Juniperus communis L. (Garciâ et al. 2000).

The depth of dormancy generally varies depending on the species, species location, or individuals at the same site (Schmidt 2000; Bewley et al. 2013). Periods of prechilling lasting eight weeks were clearly insufficient for the complete elimination of dormancy of the $F$. anatolica seeds, while they exhibited their full germination potential after 10 and 12 weeks of prechilling. The seeds from the three provenances had similar depths of dormancy and high germination rates after 10 weeks of prechilling. A 4-week warm incubation period was only slightly effective at removing dormancy. There was no evidence regarding the influence of the seed weight on germination rates, because the seeds from all provenances 
demonstrated similarly high germination percentages after full removal of dormancy. The experiments suggest that 10 weeks of prechilling is sufficient for F. anatolica seeds to escape dormancy, and that the 4-week warm-incubation period was not necessary.

A warm incubation is employed for seeds with morphological dormancy (Baskin and Baskin 2004). This study showed that $F$. anatolica seeds have mature seeds when the seeds ripen around September, having only a physiological dormancy that requires about 10 weeks of prechilling for germination. The seed coat of the seeds allows both moisture and air to enter, and thus they do not have physical dormancy.

The depth of seed dormancy is closely associated with the natural distribution of the species and the distribution range (Schmidt 2000; Fenner and Thompson 2005). In this study, the seeds from the three provenances demonstrated a similar depth of dormancy, likely because of their relatively close distribution in a limited area of the eastern Mediterranean part of Turkey.

Germination temperature is generally very effective on seed germination parameters (Bewley et al. 2013; Schmidt 2000). However, temperatures applied in these experiments only effected the time required for germination (Table 6). Among the tested temperatures, $24^{\circ} \mathrm{C}$ appeared to be most efffecttive, as germination occurred significantly later at temperatures below $20^{\circ} \mathrm{C}$. The germination temperature of a species is closely linked to the species distribution range (Baskin and Baskin 2001; Yilmaz 2005). Since the Flueggea species are distributed in warm geographic regions, the seeds demonstrated good germination behavior at $24^{\circ} \mathrm{C}$ and $28^{\circ} \mathrm{C}$. Unlike many temperate woody species, such as Fagus spp., Quercus spp., and Acer spp., the seeds did not germinate at $4^{\circ} \mathrm{C}$.

The maturation time of seeds varies with the climate, altitude, habitat, and slope, with the seeds generally ripening when they reach their maximum dry weight (Kozlowski and Pallardy 1997; Ohto et al. 2008). In this study, the seeds collected early (August 1) from low altitude (Tarsus, $300 \mathrm{~m}$ ) had a higher germination rate than seeds collected early (September 3) at high altitude (Andırın, $970 \mathrm{~m}$ ). This infers that $F$. anatolica seeds can be harvested in August and September at low altitudes, but that seeds from high altitudes should be harvested at the end of September. Seed viability is at its highest level when the seed reaches physiological maturity and begins to decrease thereafter (Priestley 1986; Yilmaz and Dirik 2008). F. anatolica seeds must be harvested from trees before their dispersal, because the fruits have a ballistic system and cannot be collected from the ground due to their size. Owing to the small size of the seeds, F. anatolica trees generally bear an abundant number of seeds each year. After collection, the
MC of the fruits should be reduced to $6-8 \%$ in perforated bags.

Seed lifespan is closely associated with the MC of the seeds and the storage temperature (Roberts 1973; Priestley 1986). Respiration and deterioration increase with rising $\mathrm{MC}$ and temperature, causing seed aging to occur more rapidly (Harrington 2012; Copeland and McDonald 2001). The results from this study indicate that the MC of $F$ anatolica seeds can be safely reduced to $2.7 \%$. Therefore, for longerterm seed storage, the seeds of this endangered plant species should be stored in seed banks with a 3-6\% MC. For short-term storage (1 year), the $F$. anatolica seeds can be stored at $4^{\circ} \mathrm{C}$. When storing orthodox seeds for longer time periods, temperatures of $-5^{\circ} \mathrm{C}$ to $-15^{\circ} \mathrm{C}$ are more suitable (Suszka et al. 1996; Li et al. 2008).

The storage characteristics of prechilled nondormant seeds vary by plant species, and prechilled nondormant seeds can be stored when MC returns to a 6-8\% level after the prechilling treatment (Edwards 1996; Chien et al. 2002; Yilmaz 2008). These experiments revealed that $F$. anatolica seeds with an $8 \%$ MC could be stored for at least one year in the refrigerator $\left(4^{\circ} \mathrm{C}\right)$, albeit with approximately a onethird loss of viability.

This study also showed that $F$. anatolica seeds have a deep physiological dormancy, and the sowing time in forest nurseries in Turkey is critical. For seed propagation, the dormant seeds should be sown around the beginning of December, thus naturally eliminating the dormancy of the seeds during the winter. On the other hand, nondormant seeds could also be sown in the spring after approximately 10 weeks of prechilling. Dry seeds of the species should not be difficult to store in seed banks for the long period. Urgent programs and projects are needed for the in situ and ex situ conservation of this endangered forest shrub species.

\section{Acknowledgment}

This study supported by The Scientific and Technological Research Council of Turkey. Project Number: 107 O 420.

\section{References}

Barker C., Van Welzen P. 2010. Flueggea (Euphorbiaceae s. I. or Phyllanthaceae) in Malesia. Systematic Botany 35: 541-551.

Baskin C.C., Baskin J.M. 2001. Seeds: Ecology, Biogeography, and Evolution of Dormancy and Germination. Elsevier. 
Baskin J.M., Baskin C.C. 2004. A classification system for seed dormancy. Seed Science Research 14: $1-16$.

Bednorz L., Walkowiak R., Maciejewska-Rutkowska I., Moliński K. 2006. Seed variability of the Polish species of the genus Sorbus (Rosaceae). Dendrobiology 55: 3-9.

Bewley J.D., Bradford K.J., Hilhorst H.W.M., Nonogaki H. 2013. Seeds: Physiology of Development, Germination and Dormancy (3rd edition). Springer, New York.

Boydak M. 1975. Researches on the seed production of scotch pine (Pinus sylvestris L.) in Eskișehir-Çatacik forests. Journal of Faculty of Forestry Istanbul University, Ser. A, 25: 159-240. (In Turkish)

Bradford K.J., Cohn M.A. 1998. Seed biology and technology: At the crossroads and beyond. Introduction to the symposium on seed biology and technology: Applications and advances and a prospectus for the future. Seed Science Research 8: 153-160.

Castro J., Hódar J.A., Gómez J.M. 2006. Seed size. In: Handbook of Seed Science and Technology Haworth Press. Basra A.S. (eds.). New York, pp. 397-427.

Chien C.-T., Chen S.-Y, Yang J.-C. 2002. Effect of stratification and drying on the germination and storage of Prunus campanulata Seeds. Taiwan Journal of Forest Science 17: 413-420.

Copeland L.O., McDonald M.B. 2001. Principles of Seed Science and Technology, 4th ed. Kluwer Academic Publishers, Massachusetts.

Desai B.B. 2004. Seeds Handbook: Biology, Production, Processing, and Storage. 2nd edn. Marcel Dekker, New York.

Edwards D.G.W. 1996. The stratificaion-redry technique with special reference to true fir seeds. In: National proceedings. Forest and conservation nursery associations. Landis T.D., South D.B. (eds.). PNW-GTR-389, pp. 172-182.

Ekim T., Koyuncu M., Duman H.,cAytaç Z., Adıgüzel N. 2000. Red data book of Turkish plants. Turkish Association for the Conservation of Nature and Van Centennial University. Barıșcan Press. (In Turkish)

Fenner M., Thompson K. 2005. The Ecology of Seeds. Cambridge University Press, Cambridge.

Flores E.M. 2002. Seed biology. In: Tropical Tree Seed Manual, USDA. Vozzo J.A. (ed.). Forest Service Agriculture Handbook 721, pp. 82-106.

Garciâ D., Zamora R., Gomez J.M., Jordano P., Hodar J.A. 2000. Geographical variation in seed production, predation and abortion in Juniperus communis throughout its range in Europe. Journal of Ecology 88: $436-446$.
Gemici Y. 1992. Flora and vegetation of Bolkar Mountains (Central Taurus). Ege University Research fund project no: 1998/011, İzmir. (In Turkish)

Gemici Y., Leblebici E. 1995. Turkey's inheritance from millions of years ago: Flueggea anatolica Gemici (Euphorbiaceae). The Karaca Arboretum Magazine 3: 79-86.

Gemici Y., Gürses M.K., Yılmaz E. 1996. Value of Kadıncik valley and its Surroundings as a nature conservation area. Directory of Open Access Journals 2: 91-113.

Harrington J.F. 2012. Seed storage and longevity. In: Seed Biology: Insects, and Seed Collection, Storage, Testing, and Certification, Vol. 3. Kozlowski T.T. (ed.). Elsevier, pp. 145-240.

Hoffman P. 2007. Phyllanthaceae. In: Flowering Plant Families of the World. Heywood V.H., Brummitt R.K., Seberg O., Culham A. (eds.). Firefly Books, Canada, pp. 250-252.

Hoffmann P., Kathriarachchi H., Wurdack K.J. 2006. A phylogenetic classification of Phyllanthaceae (Malpighiales; Euphorbiaceae sensu lato). Kew Bulletin 61: 37-53.

Govaerts R., Frodin D.G., Radcliffe-Smith A., Carter S. 2000. World Checklist and Bibliography of Euphorbiaceae (and Pandaceae) 1-4: 1-1622. The Board of Trustees of the Royal Botanic Gardens, Kew.

International Seed Testing Association 1996. International rules for seed testing. Seed Science and Technology (Supplement) 24: 1-335.

Kozlowski T.T., Pallardy S.G. 1997. Growth Control in Woody Plants. Elsevier, San Diego.

Leishman M.R., Wright I.J., Moles A.T., Westoby M. 2000. The evolutionary ecology of seed size. In: Seeds, The Ecology of Regeneration in Plant Communities. Fenner M. (ed.). CABI, pp. 31-58.

Li Y., Qu J., Dong Z., Wang T., An L.Z. 2008. Storage behavior of Zygophyllum xanthoxylon (Bge.) Maxim seeds at low moisture contents. Acta Physiologiae Plantarum 30: 651-656.

Michaels H.J., Benner B., Hartgerink A.P., Lee T.D., Rice S., Willson M.F., Bertin R.I., 1988. Seed size variation: magnitude, distribution and ecological correlates. Evolutionary Ecology 2: 157-166.

Odabaşı T. 1967. Researches on the seeds and cones of Lebanon cedar (Cedrus libani Loud.). Journal of Faculty of Forestry Istanbul University, Ser. A 17: 136-174.

Ohto M., Stone S.L., Harada J.J. 2008. Genetic control of seed development and seed mass. In: Seed Development, Dormancy and Germination. Bradford K.J., Nonogaki H. (eds.). Blackwell, Oxford, pp. 1-24.

Ok T. 2006. The studies on native range, some biological and ecological characteristics of Flueggea ana- 
tolica Gemici. MSc Thesis, Kahramanmaras Sutcu Imam University, Kahramanmaras.

Ok T., Avşar M.D. 2007. A new locality of Kadıncık shrub (Flueggea anatolica Gemici) in Turkey. Süleyman Demirel Üniversitesi Orman Fakültesi Dergisi 2: 102-106. (In Turkish)

Ok T., Avşar M.D. 2009. New distribution area of Kadıncik shrub (Flueggea anatolica Gemici) in the Andırın region Kahramanmaraş, Turkey. Biodicon 281: 65-70.

Özhatay N., Byfield A., Atay S. 2003. Important plant areas of Turkey, WWF Turkey, Istanbul.

Priestley D.A. 1986. Seed Aging: implications for seed storage and persistence in the soil. Comstock Associates, Ithaca.

Royal Botanic Garden Kew 2014. Seed Information Database. http://data.kew.org/sid. (Access: February, 2014)

Roberts E.H. 1973. Predicting the storage life of seeds. Seed Science and Technology 1: 499-514.

Schmidt L. 2000. Guide to Handling of Tropical and Subtropical Forest Seed. Danida Forest Seed Centre, Denmark.

Serdar B., Hayden W.J., Terzioglu S. 2008. Wood anatomy of Flueggea anatolica (Phyllanthaceae). IAWA Journal 29: 303-310.

Şefik Y. 1964. Researches on the cones and seeds of Turkish red pine (Pinus brutia Ten.). Journal of Faculty of Forestry Istanbul University, Ser. A, 14: 35-67. (In Turkish)

Smith M.T., Wang B.S.P., Msanga H.P. 2002. Dormancy and germination. In: Tropical Tree Seed Manual,
USDA. Vozzo J.A. (ed.). Forest Service Agriculture Handbook 721, pp. 149-176.

Suszka B., Muller C., Bonnet-Masimbert M. 1996. Seeds of Forest Broadleaves: From Harvest to Sowing, INRA. Editions Quae, France.

Thomsen K.A., Kjaer E.D. 2002. Variation between single tree progenies of Fagus sylvatica in seed traits, and its implications for effective population numbers. Silva Genetica 51: 183-190.

Thomson L.A.J. 2006. Flueggea flexuosa (poumuli), ver. 2.1. In: Species profiles for Pacific Island agroforestry. Elevitch C.R. (ed.). Permanent Agriculture Resources, Hawaii.

Webster G.L. 1984. A revision of Flueggea (Euphorbiaceae). Allertonia 3: 259-312.

Yilmaz M. 2005. The researches on the physiology of oriental beechnuts (Fagus orientalis Lipsky). PhD Thesis, Istanbul University, Institute of Science. (in Turkish)

Yilmaz M. 2008. Optimum germination temperature. dormancy and viability of stored non-dormant seeds of Malus trilobata (Poir). C.K. Schneid. Seed Science and Technology 36: 747-756.

Yilmaz M., Dirik H. 2008. Maturation of oriental beechnuts (Fagus orientalis Lipsky). Dendrobiology 60: 57-62.

Yilmaz M., Tonguç F. 2009. Fruit and seed size variability of Fraxinus ornus subsp. cilicica. International Journal of Natural and Engineering Sciences 3: 133-136. 